\title{
Prioritization of Forest Restoration Projects: Tradeoffs between Wildfire Protection, Ecological Restoration and Economic Objectives
}

\author{
Kevin C. Vogler ${ }^{1, *}$, Alan A. Ager ${ }^{2}$, Michelle A. Day ${ }^{3}$, Michael Jennings ${ }^{4}$ and John D. Bailey ${ }^{1}$ \\ Received: 1 October 2015; Accepted: 19 November 2015; Published: 1 December 2015 \\ Academic Editors: Jean-Claude Ruel and Eric J. Jokela \\ 1 Department of Forest Engineering, Resources and Management, College of Forestry, \\ Oregon State University, 043 Peavy Hall, Corvallis, OR 97331, USA; john.bailey@oregonstate.edu \\ 2 USDA Forest Service, Rocky Mountain Research Station, 72510 Coyote Road, Pendleton, OR 97801, USA; \\ aager@fs.fed.us \\ 3 Department of Forest Ecosystems and Society, College of Forestry, Oregon State University, \\ 321 Richardson Hall, Corvallis, OR 97331, USA; michelle.day@oregonstate.edu \\ 4 USDA Forest Service, La Grande Forestry and Range Science Lab, 1401 Gekeler Lane, La Grande, OR 97850, \\ USA; michaeldjennings@fs.fed.us \\ * Correspondence: kevin.vogler@oregonstate.edu; Tel.: +1-541-737-1563
}

\begin{abstract}
The implementation of US federal forest restoration programs on national forests is a complex process that requires balancing diverse socioecological goals with project economics. Despite both the large geographic scope and substantial investments in restoration projects, a quantitative decision support framework to locate optimal project areas and examine tradeoffs among alternative restoration strategies is lacking. We developed and demonstrated a new prioritization approach for restoration projects using optimization and the framework of production possibility frontiers. The study area was a 914,657 ha national forest in eastern Oregon, US that was identified as a national priority for restoration with the goal of increasing fire resiliency and sustaining ecosystem services. The results illustrated sharp tradeoffs among the various restoration goals due to weak spatial correlation of forest stressors and provisional ecosystem services. The sharpest tradeoffs were found in simulated projects that addressed either wildfire risk to the urban interface or wildfire hazard, highlighting the challenges associated with meeting both economic and fire protection goals. Understanding the nature of tradeoffs between restoration objectives and communicating them to forest stakeholders will allow forest managers to more effectively design and implement economically feasible restoration projects.
\end{abstract}

Keywords: production possibility frontiers; restoration prioritization; ecosystem services; restoration tradeoffs

\section{Introduction}

Forest management practices over the past century or more have altered natural fire regimes, leaving large areas of national forests in the western United States (US) susceptible to both high-severity wildfire events [1] and large-scale insect disturbances [2]. Frequent, large-scale disturbances have deleterious impacts on the production of ecosystem services [3] and threaten both life and property. Additionally, the scale and frequency of these disturbances are predicted to increase with a warming climate [4,5], further jeopardizing the sustainability of forests and their associated ecosystem services [6]. In order to address these issues, public land managers in the US and elsewhere have initiated accelerated restoration programs $[7,8]$ to restore forest stand composition and structure in order to create fire resilient forests. Restoration goals also include the production of provisional 
ecosystem services in the form of wood products to provide economic benefits to rural communities [7]. Forest restoration activities include thinning, mastication and site removal of surface fuels, broadcast burning and a range of other techniques [9].

Implementing forest restoration programs requires identification of priority landscapes to ensure efficient use of finite financial resources. Prioritization of public forest restoration projects is a complex undertaking given the multi-use mandate of forests and the expectation of meeting a broad mix of socioeconomic and ecological goals [10]. Despite this complexity, quantitative decision support tools to assist in identifying priority landscapes and examine tradeoffs among alternative restoration strategies are lacking. Previous efforts have leveraged decision support methods such as fuzzy logic [11] and simulated annealing [12] but have not found widespread application due to complex technical and data requirements. Application of decision support tools that utilize the large array of optimization methods available for prioritization [13,14] within a management context requires improvements in model accessibility. Optimization methods, although complex, can be used to identify the opportunity cost of alternative treatment strategies and inform managers of areas where greater restoration or economic gains may be attained, improving the long-term chance of successful restoration programs [15].

Tradeoffs between restoration objectives and subsequent opportunity costs of management decisions can be analyzed through a production possibility frontier (PPF) framework. Theoretical PPFs are graphical representations depicting the tradeoffs between two inputs in pursuit of a desired output level (Figure 1). In the context of this study, PPF relationships can be used to help understand how the distributions of both forest stressors and ecosystem services define restoration options across the landscape. This approach has also been used in both forested [16-18] and aquatic systems [19-21] to analyze tradeoffs between economic returns and conservation values.

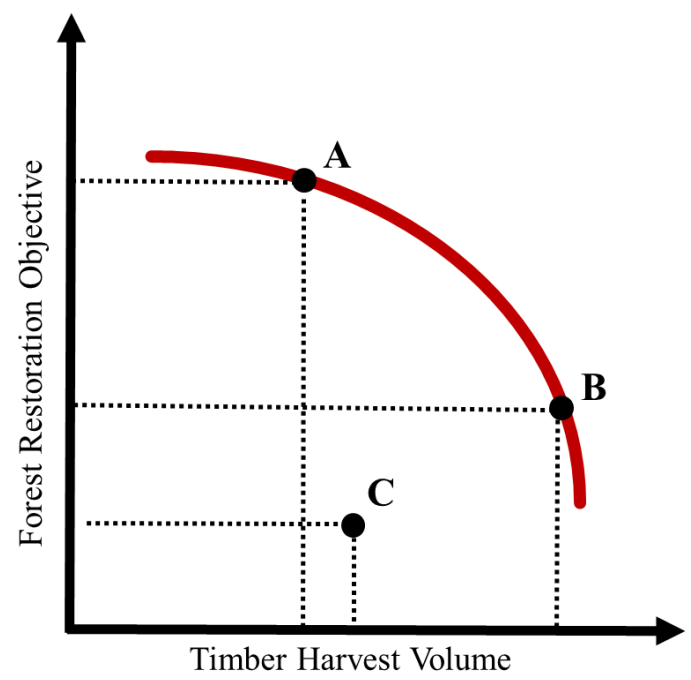

Figure 1. This hypothetical production possibility frontier (PPF) compares the tradeoff between the attainment of forest restoration objectives and production of timber harvest volume. All points located along the PPF curve (point A, for example) represent the most efficient combination of inputs possible (area treated). In other words, for each point occurring along the curve more of one restoration objective cannot be attained without sacrificing the other. Point $C$ represents a project that is suboptimal relative to point $\mathrm{A}$, in part because it is inefficient (i.e., efforts could be reallocated to either restoration objective in order to get more of each).

Little work has been done to understand the tradeoffs between potentially competing forest restoration strategies [22]. While forest restoration goals can be compatible, choosing one particular emphasis leads to inherent management tradeoffs due to a scarcity of lands that meet all restoration objectives. In this paper, we used optimization methods to analyze priorities and tradeoffs among a range of socioecological objectives affecting ecosystem services on a large fire-prone national forest 
in eastern Oregon, US. This study area has been targeted as a national priority for restoration with the goal of improving fire resiliency and sustaining ecosystem services. We used a relatively simple optimization model to prioritize 42 planning areas and analyze tradeoffs among restoration objectives within each area. Specifically, we examined the following questions: (1) are there clearly identifiable high-priority planning areas to target restoration efforts with respect to the attainment of multiple objectives; (2) what tradeoffs exist between prioritizing restoration of forest stressors and producing provisional ecosystem services (e.g., timber); and (3) to what extent do production possibility frontiers vary among planning areas? We discuss the results in the context of applying our methods to help forest managers understand how the spatial distribution of restoration priorities and the nature of tradeoffs can inform restoration programs that maintain the sustainable production of ecosystem services.

\section{Methods}

\subsection{Study Area}

The study area is the Wallowa-Whitman National Forest (henceforth "Forest") located in the Blue Mountain ecoregion of eastern Oregon (914,657 ha, Figure 2). Elevations vary greatly across the Forest from $267 \mathrm{~m}$ in the Hells Canyon National Recreation Area to $3001 \mathrm{~m}$ in the Eagle Cap Wilderness. The Forest is dominated by ponderosa pine (Pinus ponderosa Lawson \& C. Lawson) dry forest in the lower elevations and by dry mixed conifer (Abies grandis (Douglas ex D. Don) Lindl. and Pseudotsuga menziesii (Mirb.) Franco) and moist conifer forests at the higher elevations. Homogenous lodgepole pine (Pinus contorta Douglas ex Loudon) stands dominate the area at mid to high elevations representing cold, dry forest. The pre-settlement conditions in the lower elevations consisted primarily of open ponderosa pine stands with a relatively low density of mature trees.

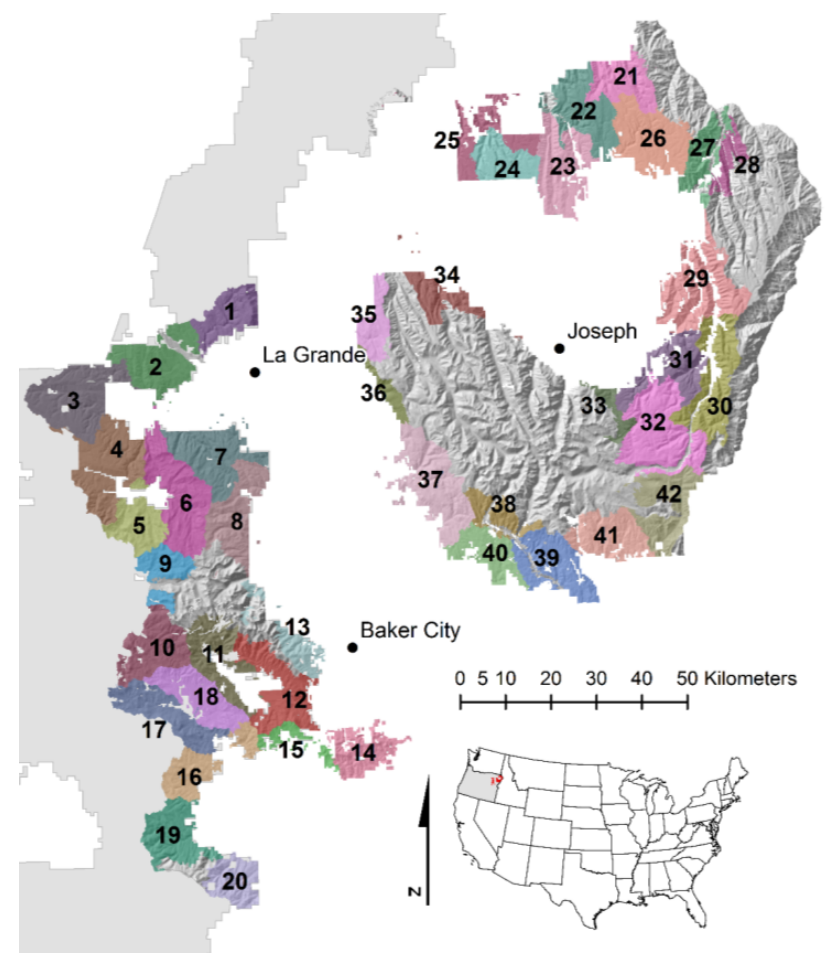

\begin{tabular}{|c|c|}
\hline \multicolumn{2}{|c|}{$\begin{array}{l}\text { Willowa-Whitman NF } \\
\text { Planning Areas }\end{array}$} \\
\hline 1 - Five Points $\mathrm{Cr}$ & 22 - Mid Joseph/Lwr Joe \\
\hline 2 - Spring $\mathrm{Cr}$ & 23 - Upr Joseph/Lwr Joe \\
\hline 3 - Meadow $\mathrm{Cr}$ & 24 - Muddy Sled \\
\hline 4 - Starkey/Umapine & 25 - Kuhn Ridge \\
\hline 5 - Sheep Cr & 26 - Chesnimnus \\
\hline 6 - Limber Jim & 27 - Buckhorn \\
\hline 7 - Beaver $\mathrm{Cr}$ & 28 - Lower Imnaha \\
\hline 8 - East Face & 29 - Imnaha \\
\hline 9 - Trail $\mathrm{Cr}$ & 30 - Puderbaugh \\
\hline 10 - Granite & 31 - Big Sheep \\
\hline 11 - Craker $\mathrm{Cr}$ & 32 - Morgan Nesbit \\
\hline 12 - Little Dean/Union Miners & 33 - Cold Canal \\
\hline 13 - Elkhorn Face & 34 - Sage \\
\hline 14 - Rooster & 35 - Clark \\
\hline 15 - Sundry & 36 - Cove \\
\hline 16 - Middle Fork Burnt R & 37 - Sandbox \\
\hline 17 - Patrick & 38 - Basin Bennet \\
\hline 18 - Whitney Valley & 39 - Pine Valley \\
\hline 19 - Rail & 40 - Snow Basin \\
\hline 20 - Camp $\mathrm{Cr}$ & 41 - Clear $\mathrm{Cr}$ \\
\hline 21 - Lwr Joseph/Lwr Joe & 42 - North Pine NRA \\
\hline
\end{tabular}

Figure 2. Map of the planning areas within the Wallowa-Whitman National Forest. Planning areas ranged in size from 1569 to 10,377 ha and only include stands that are available for active forest management.

The Forest has been clear cut and selectively logged since the 1920s, resulting in a mosaic of stand ages, density, and species composition. Wildfires and insect outbreaks are common disturbances across 
the Forest and have impacted stand structure and composition over vast areas [23,24]. Currently, 71\% of the non-reserved forest area is in a moderately departed condition and $8 \%$ is in a highly departed condition as compared to the historical rage of variability. Wildfire is a frequent disturbance agent with an average of 121 ignitions per year across this landscape. These fires were predominantly lighting caused (78\%) and burned an average of 11,352 ha per year with an average fire size of 94 ha (0.01-32,030 ha) [25]. In addition to the current ecological departure and disturbances by wildfires, insects present a significant management issue across the Forest. Major insect epidemics have been observed for spruce budworm, bark beetles, and tussock moth in the last 30 years. Currently, 267,172 ha or $45 \%$ of the manageable area on the Forest is at risk of at least a $25 \%$ basal area loss within the next 15 years due to insect infestation. To address these and other forest management issues, the Forest implements restoration treatments on an average of 3647 ha per year generating approximately $125,400 \mathrm{~m}^{3}$ of timber annually. Current prioritization of restoration treatments is not standardized and employs ad hoc methods based on a synthesis of field observations and inventory data.

\subsection{Modeled Restoration Objectives}

After reviewing planning documents and meeting with Forest planning staff we selected five treatment objectives for analyses: vegetation departure, insect risk, timber volume, wildfire risk to the wildland urban interface (WUI), and potential wildfire hazard. These management objectives mirror the priorities on many other national forests in the western US [7]. Each of these objective variables was attributed to a forest polygon layer $(n=55,886)$ obtained from USDA Forest Service corporate data. The stand polygon layer was originally created in the early 1980s from aerial photo delineation and is continually updated by the Forest for disturbance and management activities. Additionally, each polygon stand was attributed with the land management designation from the Forest Plan. Protected areas (wilderness, roadless, special interest areas, and research natural areas) were removed from consideration for restoration treatments. The remaining data consisted of 46,293 polygons (forest stands) ranging in size from 0.4 ha to 401 ha with an average size of 12.7 ha, and covered 589,336 ha of the Forest (64.4\% of total land area).

\subsection{Vegetation Departure from Reference Conditions}

Vegetation departure from historical reference conditions is a metric widely used by the Forest Service to quantify restoration need. To quantify vegetation departure in the study area, we obtained a $30 \mathrm{~m}$ resolution national-scale map of vegetation departure created by the LANDFIRE project [26] using methods described by Hann et al. [27], with modifications described by Rollins et al. [28]. The Vegetation Departure (VDEP) data layer categorizes and scores departure between simulated current vegetation conditions and historical vegetation conditions. The departure score ranges from 0 to 100 representing the percentage departure from historical conditions. High values of vegetation departure on the Forest indicate increases in stand density and changes in species composition. Fire-tolerant species (e.g., ponderosa pine) are generally replaced by more fire-intolerant species (e.g., grand fir). The data were averaged for each planning area polygon (Figure $3 \mathrm{~A}$ ) and the average value was used to calculate a stand-level metric which represented the total number of hectares in a departed condition. 

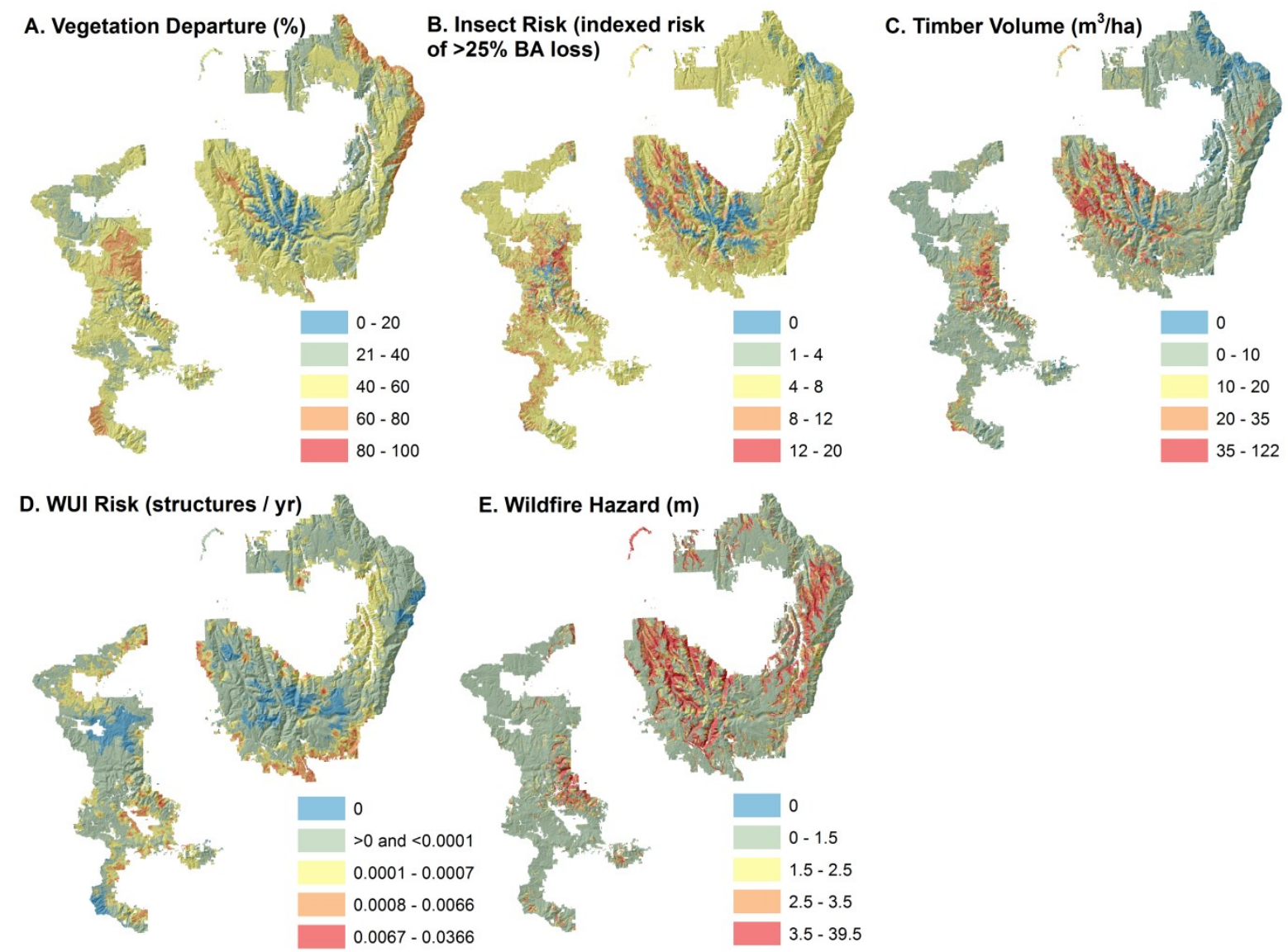

Figure 3. Spatial distribution of restoration objective values within the Wallowa-Whitman National Forest for (A) vegetation departure; (B) insect risk; (C) total merchantable timber volume generated from restoration treatments; (D) wildland urban interface (WUI) risk based on the number of structures lost per year from wildfires ignited on national forest land; and (E) wildfire hazard calculated as potential flame length.

\subsection{Insect Risk}

Insect epidemics influence management objectives and restoration treatment opportunities due to forest health concerns. Insect risk data were obtained from Jennings [29]. Spatial data for mountain pine beetle (Dendroctonus ponderosae Hopkins) risk in both lodgepole pine and ponderosa pine, and western pine beetle (Dendroctonus brevicomis LeConte) risk in ponderosa pine were combined to show at a landscape scale the levels of risk for tree mortality from pine beetle. Each insect risk data layer represents an index of the relative risk of at least $25 \%$ basal area mortality attributed to pine beetle; the index values were summed and attributed to the management stand layer (Figure 3B).

\subsection{Timber Harvest Volume}

The timber volume harvested off the Forest provides an important ecosystem service for the region, as well as providing economic benefit to rural communities, and is thus a focus of management efforts. Potential harvest volume data were obtained from the Landscape, Ecology, Modeling, Mapping and Analysis project (LEMMA, [30]) using imputed Forest Inventory Data (FIA) plot data for each $30 \mathrm{~m} \times 30 \mathrm{~m}$ pixel in the study area. The statistical imputation uses a gradient nearest neighbor (GNN) imputation procedure [30] to assign coarse-scale FIA plot data based on associations of satellite, topographic, and other data. The GNN grid of inventory plots was intersected with the stand polygon layer and the population of $30 \mathrm{~m}$ pixels that represented each plot was identified. The Blue Mountains variant of the Forest Vegetation Simulator (FVS) [31] was used to simulate a restoration thinning in 
each stand using prescriptions adopted from operational practices by Forest silviculturists developed in previous studies [32,33]. The thinning is based on stand density index (SDI) [34] targets established in the Blue Mountains for each target tree species and plant association [35-37]. Stands where the SDI exceeded $65 \%$ of the maximum were thinned with the tree removal ordered from smallest to largest, thus reducing ladder fuels that contribute to crown fire. Stands were thinned to $35 \%$ of the maximum SDI for the stand. We used an FVS thinning efficiency [31] of $90 \%$, so that $10 \%$ of the trees in each thinned size class were retained for crop trees. In mixed species stands, prescriptions targeted thinning of late-seral, fire-intolerant species (e.g., grand fir) and retention of fire-tolerant early seral species (e.g., ponderosa pine). The species preferences differed by plant association group [36] as described in Ager et al. [32]. We averaged the total merchantable thin volume as defined and reported by FVS [38] for each stand (Figure 3C) and then estimated a total volume from the thinning treatment by multiplying by the stand area.

\subsection{Wildfire Risk to the WUI}

The wildland urban interface (WUI) continues to be an important consideration for appropriate management action. We measured the wildfire risk transmission to the WUI adjacent to the Forest using SILVIS WUI data [39] for the study area. We removed SILVIS polygons that were: (1) classified as uninhabited; (2) classified as water; (3) less than 0.1 ha in size; or (4) more than $10 \mathrm{~km}$ from the national forest boundary following the methods of Ager et al. [40]. We maintained polygons with even low population or structure densities to reflect fire suppression efforts targeting single, individual structures in wildland areas during management operations. There were a total of 52,202 WUI polygons covering an area of over 1.6 million ha across the Forest.

Wildfire simulation outputs generated from the 2014 version of the large fire simulator model, FSim [41], were then used to quantify WUI area burned by wildfires ignited on the adjacent Forest. FSim has been extensively described elsewhere [41], but in general the model simulates wildfire ignitions and perimeters for a large number (e.g., $\geqslant 20,000)$ of hypothetical wildfire seasons based on historical relationships between Energy Release Component (ERC) and large fire occurrence data (1992-2011). Daily probability of an ignition is modeled based on logistic regression of historical fire occurrence and ERC. Hypothetical wildfire seasons were simulated with annual weather scenarios based on ERC, daily and seasonal trends and variability in ERC based on time-series analysis and wind speed and direction distributions from Western Regional Climate Center [42] surface weather records.

Simulation outputs used in this study were generated as part of the Fire Program Analysis project [43] with surface and canopy fuels and topography data obtained from the most updated LANDFIRE data (2010 Refresh) available at the time of simulations. Random ignition locations were assumed, and fires were simulated at a $270 \mathrm{~m} \times 270 \mathrm{~m}$ pixel resolution with random ignitions [41]. A total of 37,286 simulated ignitions and associated perimeters representing 20,000 fire season replicates were included in the current study.

Fire perimeters associated with ignitions occurring within the Forest boundary were intersected with WUI boundaries to determine the WUI area burned annually by each ignition. The number of structures burned by each ignition point was calculated as the product of the housing units in the polygon and the proportion of the polygon burned. To generate a $0.5 \mathrm{~km}$ smoothed raster surface of WUI risk (structure loss) for the Forest, we applied an inverse distance weighting model to the point data using a $5 \mathrm{~km}$ fixed search radius for the entire study area. WUI risk (structure loss) (Figure 3D) and stand-level structure loss (average WUI risk multiplied by the stand area) were attributed to each stand polygon.

\subsection{Potential Wildfire Hazard}

In addition to assessing the WUI risk posed by wildfire, a variable representing the potential wildfire hazard on the landscape was also derived. We used the FlamMap wildfire simulation program (USDA Forest Service, Rocky Mountain Research Station, Fort Collins, CO, US) [44] to estimate flame 
length $(\mathrm{m})$ at $90 \mathrm{~m} \times 90 \mathrm{~m}$ resolution within the study area using the "basic fire behavior" subsystem in FlamMap, calculating fire behavior by independently burning each pixel on the landscape. Wildfire simulation parameters were used from a previous study in the area and represented 97th percentile weather conditions for the central Blue Mountains (see Table 1 in [32]). Surface and canopy fuels along with topography were also obtained from the national LANDFIRE dataset $[45,46]$ and included elevation (m), slope (degrees), aspect (azimuth), fuel model [47], canopy cover (percent), canopy base height $(\mathrm{m})$, canopy height $(\mathrm{m})$, and canopy bulk density $\left(\mathrm{kg} \cdot \mathrm{m}^{-3}\right)$. These simulation methods are similar to those used by other national forests to identify high fire hazard stands for treatment. We then calculated the average flame length $(\mathrm{m})$ for each stand (Figure $3 \mathrm{E}$ ) as well as the stand level total flame length, the product of the average flame length and the stand area, representing the total fire intensity released if the polygon burned.

\subsection{Prioritizing Project Areas}

We used the Landscape Treatment Designer (LTD) (USDA Forest Service, Pacific Northwest Research Station, Portland, OR, US) [48] to determine priority planning areas for each restoration objective. We modeled a scenario where a maximum of 1619 ha were selected for treatment within each planning area, which represents the average treated area per project within the study area over the past five years. We assumed that treatments would address each of the restoration objectives (i.e., vegetation departure, insect risk, WUI risk, and wildfire hazard), consistent with assumptions made during National Forest System operational project planning and prioritization [49]. A stand selected for treatment would contribute to the total objective value attainment within a planning area. To remove potential bias from polygon size, the area weighted average stand level objective value was used. This value was calculated for an objective as the average stand level value divided by the maximum value within the study area for that objective. This method standardized the weighting of objectives that are not equally scaled. To standardize reporting between restoration metrics, the overall optimality of the project was based on the sum of the stand level objective attainment for the project represented as a percentage of the total objective value for all stands within the manageable landscape. We refer to this value as the percent contribution to the problem. It is the objective value of an individual stand divided by the sum of all values within the landscape. Each of the five restoration objectives were maximized within each planning area, resulting in an optimized sequence of projects and associated restoration outputs.

\subsection{Examining Tradeoffs}

We examined tradeoffs between combinations of different restoration objectives described above by iteratively changing the relative objective weights between combinations of objectives and rerunning LTD. Specifically, we examined the impact of thinning volume (provisional ecosystem service) with increased weighting of the coefficients for other restoration objectives. We focused the analysis on this tradeoff relationship because the economics of restoration projects are critical to scaling up the pace and extent of treatments and meeting the goal of providing economic benefit to rural communities. For each pairwise comparison, we varied the weights for the two objectives between 0 and 5 in increments of 1 . The outputs were used to generate PPF relationships between harvest volume and each restoration objective (e.g., vegetation departure).

\section{Results}

\subsection{Priority Planning Areas}

The location of priority restoration areas and the ability to treat the landscape-level problem varied widely both across the study area and between objectives (Figure 4). Project attainment is a measure of the degree to which an individual project addressed the total landscape level restoration problem. LTD reports project attainment as the sum of the objective contribution of all treated stands. 
The contribution of an individual stand is calculated by dividing the stand objective value by the sum of the stand objective values for all stands within the study area. For example, the total landscape level problem for WUI risk is calculated by summing the total number of hectares that contribute to the loss of structures from wildfire transmission into the WUI. The percentage of these hectares that are treated by a 1619 ha project is the project level attainment (\% reduction of total landscape problem) for WUI risk reduction. For timber volume, this refers simply to the amount of merchantable timber $\left(\mathrm{m}^{3}\right)$ generated from a project. The ability of individual projects to address the total landscape level problem varied greatly between restoration objectives (Figure 4). WUI risk had the greatest range from the most to least optimal planning areas $(0.01 \%-6.10 \%)$ due to the majority of restoration problem areas being clustered in planning areas within close proximity to rural-urban centers. Vegetation departure had the smallest range of attainment $(0.27 \%-0.45 \%)$ of all considered objectives due to the generally ubiquitous nature of vegetation departure across the landscape.

Priority restoration areas were determined by ranking each planning area 1-42 based on the project level attainment of each objective variable. No planning area was ranked as the highest priority for all restoration objectives (Figure 5). It should be noted that planning area priorities were based on a project that was optimized for a particular restoration objective and the joint production of multiple restoration objectives may not be possible within a planning area. Only a single planning area was ranked highest for two objective variables: insect risk and timber volume and was second priority for vegetation departure. Only two planning areas were ranked in the top ten for four of the restoration objectives, and six planning areas were in the top ten for three restoration objectives. Thus opportunities to increase restoration treatment effectiveness were limited to targeting and prioritizing higher ranking planning areas.

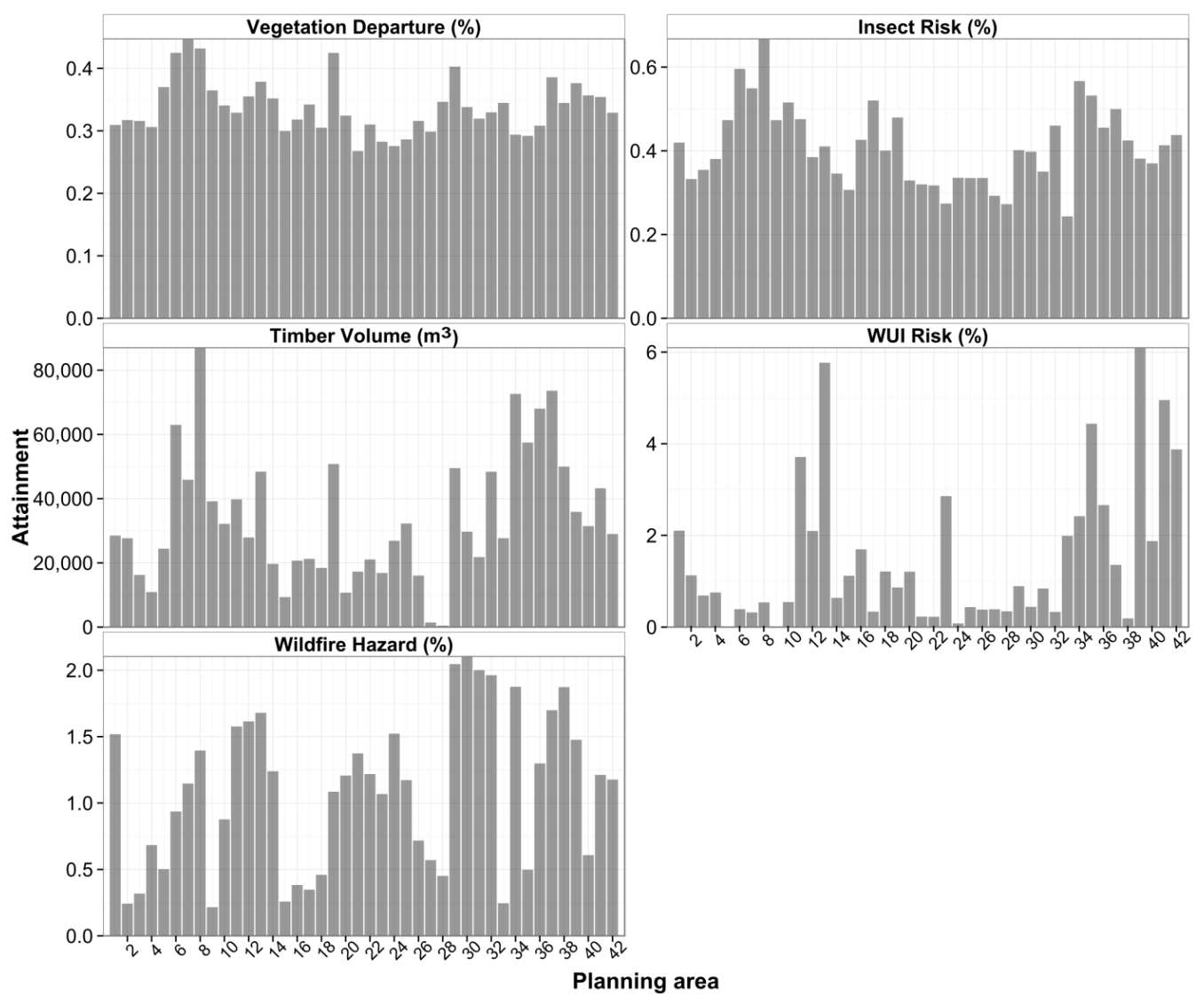

Figure 4. Simulated attainment (percent of landscape total or total timber volume) of restoration objectives from one 1619 hectare restoration project per planning area on the Wallowa-Whitman National Forest using the Landscape Treatment Designer. 
The Forest has initiated projects within 11 planning areas since 2012. Projects are currently at various stages of development and are shown in Table 1. Projects tended to match modeled high-priority planning areas (e.g., East Face and Little Jim), however, projects were also located in planning areas that our results indicated were a low priority for restoration (e.g., Snow Basin and Cold Canal). These projects may have been developed to address specific stand level management issues that are beyond the scope of this work or could be viewed as an example of how the utilization of quantitative prioritization tools may have resulted in different project priorities during planning.

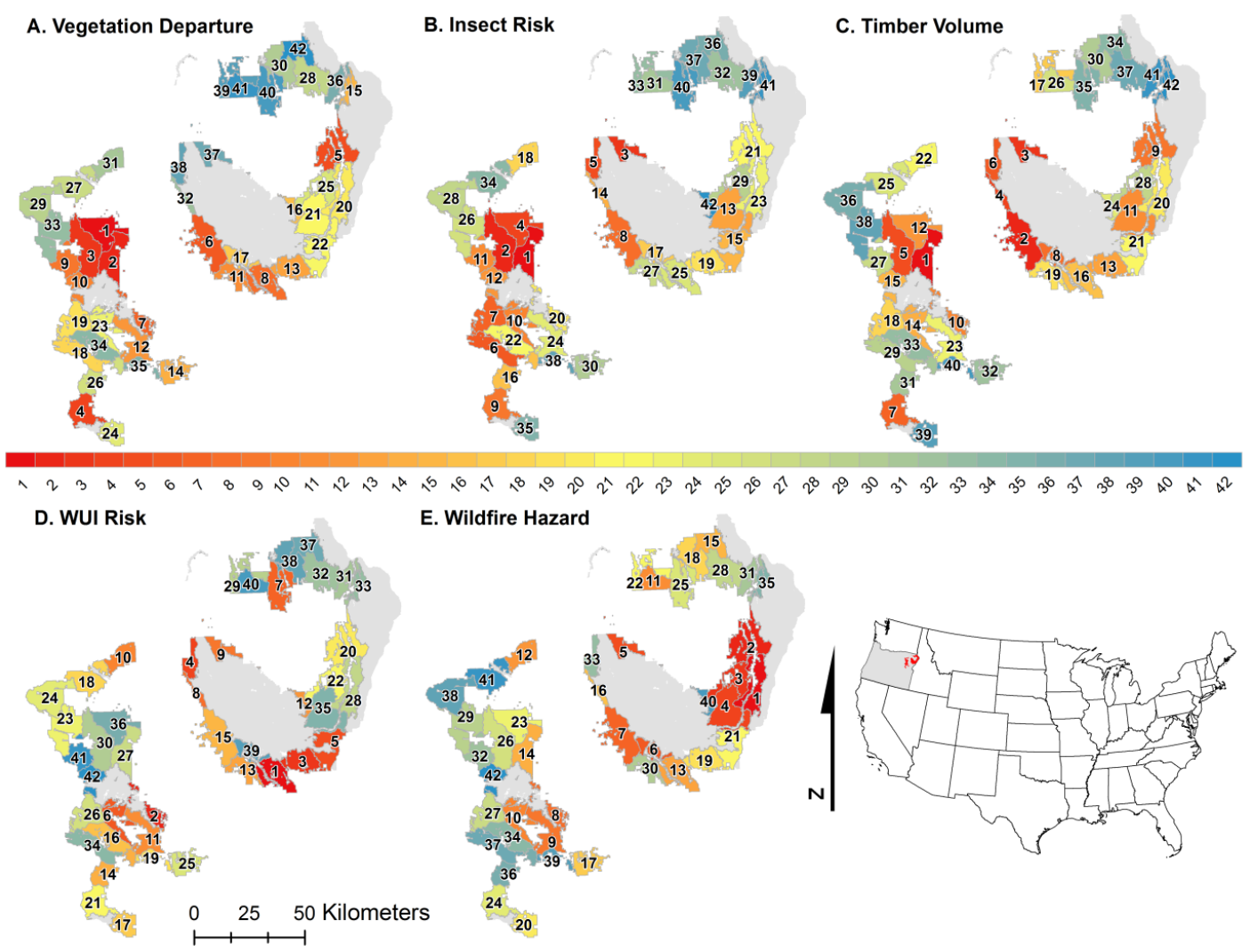

Figure 5. Project planning area priorities within the Wallowa-Whitman National Forest for (A) vegetation departure; (B) insect risk; (C) total merchantable timber volume generated from restoration treatments; (D) wildland urban interface (WUI) risk based on the number of structures lost per year from wildfires ignited on national forest land; and (E) wildfire hazard calculated as potential flame length. Planning areas were ranked based on outputs from the Landscape Treatment Designer. The area labeled " 1 " represents the highest priority planning area for the given restoration objective.

Table 1. Ranking of active forest restoration planning areas on the Wallow-Whitman National Forest since 2012 of the 42 simulated using the Landscape Treatment Designer for each of five restoration scenarios optimized independently.

\begin{tabular}{|c|c|c|c|c|c|}
\hline Planning Area & Vegetation Departure & Insect Risk & Timber Volume & WUI Risk & Wildfire Hazard \\
\hline Five Points Creek & 31 & 18 & 22 & 10 & 12 \\
\hline Limber Jim & 3 & 2 & 5 & 30 & 26 \\
\hline East Face & 2 & 1 & 1 & 27 & 14 \\
\hline Little Dean/Union Miners & 12 & 24 & 23 & 11 & 9 \\
\hline Rail & 4 & 9 & 7 & 21 & 24 \\
\hline Puderbaugh & 20 & 23 & 20 & 28 & 1 \\
\hline Morgan-Nesbit & 21 & 13 & 11 & 35 & 4 \\
\hline Cold Canal & 16 & 42 & 24 & 12 & 40 \\
\hline Cove & 32 & 14 & 4 & 8 & 16 \\
\hline Sandbox & 6 & 8 & 2 & 15 & 7 \\
\hline Snow Basin & 11 & 27 & 19 & 13 & 30 \\
\hline
\end{tabular}




\subsection{Restoration Tradeoffs}

Prioritization of a single planning area based on one of our restoration objectives may lead to attainment of other objectives within a planning area, but not likely within the same forest stand. Filtering the forest stand data to $10 \%$ of the landscape $(60,703 \mathrm{ha})$ that achieved the highest restoration potential for each of the restoration objectives, showed no overlap among stands for all five metrics (Figure 6A). Of the 60,703 ha in each of the four objectives (potential of 242,811 hectares if there is no overlap), 39,798 ha contained two or more highly objective valued stands. This overlap was further reduced if restoration projects required treatments to generate sufficient timber volume to offset the cost of the treatment (filter all stands that generated less than $14 \mathrm{~m}^{3} \cdot \mathrm{ha}^{-1}$ ); only 2753 ha contained high restoration potential for two or more objectives (Figure 6B). The limited overlap of high-priority stands (scarcity), especially those with economically viable treatment options, created tradeoff scenarios for any planned restoration project.

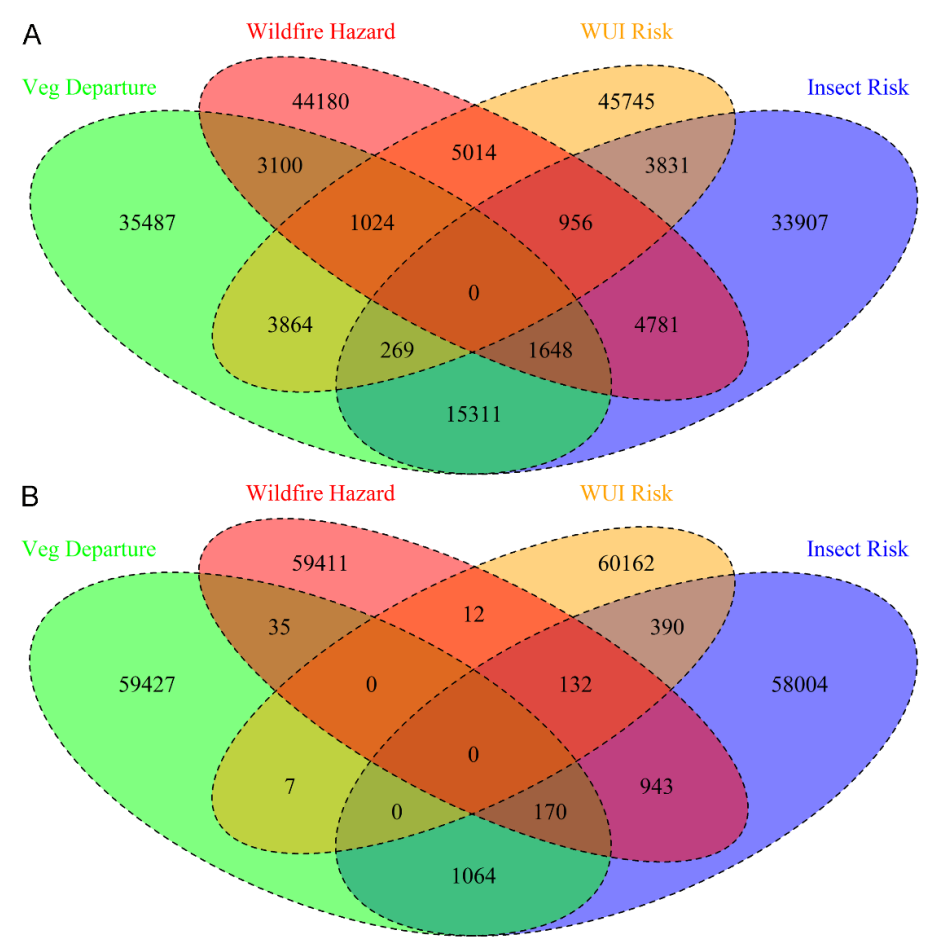

Figure 6. (A) Total area (ha), and (B) total area (ha) with sufficient timber volume to offset the cost of the treatment $\left(14 \mathrm{~m}^{3} \cdot \mathrm{ha}^{-1}\right)$, and potential overlap of forest stands with the highest restoration potential for each of the five restoration objectives for $10 \%$ of the manageable landscape (60,703 ha). Overlapping areas represent opportunities to achieve more than one restoration objective within the same hectare. Each ellipse represents an equal number of hectares and overlaps between objectives are not drawn to scale.

\subsection{Production Possibility Frontiers}

In general the PPFs exhibited concave curves, indicating tradeoffs were present for each of the restoration objectives. In addition, projects that emphasized timber production always led to a tradeoff in the production of the other paired restoration objective. This tradeoff was steeper in some planning areas than others, and steeper for some restoration objectives relative to others (Figures 7-10). A steeper tradeoff indicates a lack of co-location of restoration objectives and timber harvest volume. The PPFs also highlight planning areas that represent poor choices for achieving either restoration objective, as well as identifying those that represent the greatest opportunity for joint production of the restoration objectives. 


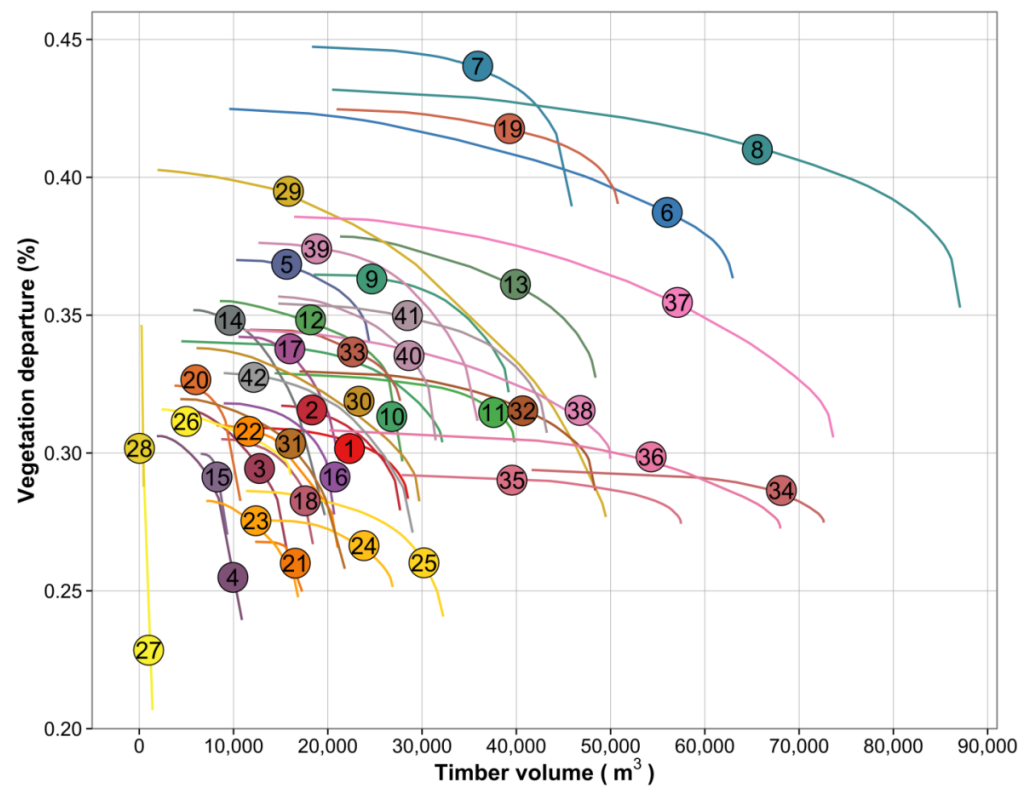

Figure 7. Production possibility frontier between total merchantable timber volume and treatment of the total landscape level vegetation departure restoration problem on the Wallowa-Whitman National Forest.

Comparison of the attainment of timber volume and the reduction in vegetation departure showed a large number of planning areas with opportunities for joint production of both objectives (Figure 7). A steep tradeoff relationship was seen in the Imnaha (PA29) planning area where a significant loss of vegetation departure restoration would be necessitated in order to increase timber production. The marginal opportunity cost of increasing timber production in Imnaha was greater than in Limber Jim (PA6) or East Face (PA8) where there are opportunities to increase timber production without significant tradeoffs in the reduction of vegetation departure. Gradual slopes of the PPF relationship also provide opportunities to prioritize stands for additional highly valued resources, such as threatened and endangered species or riparian areas.

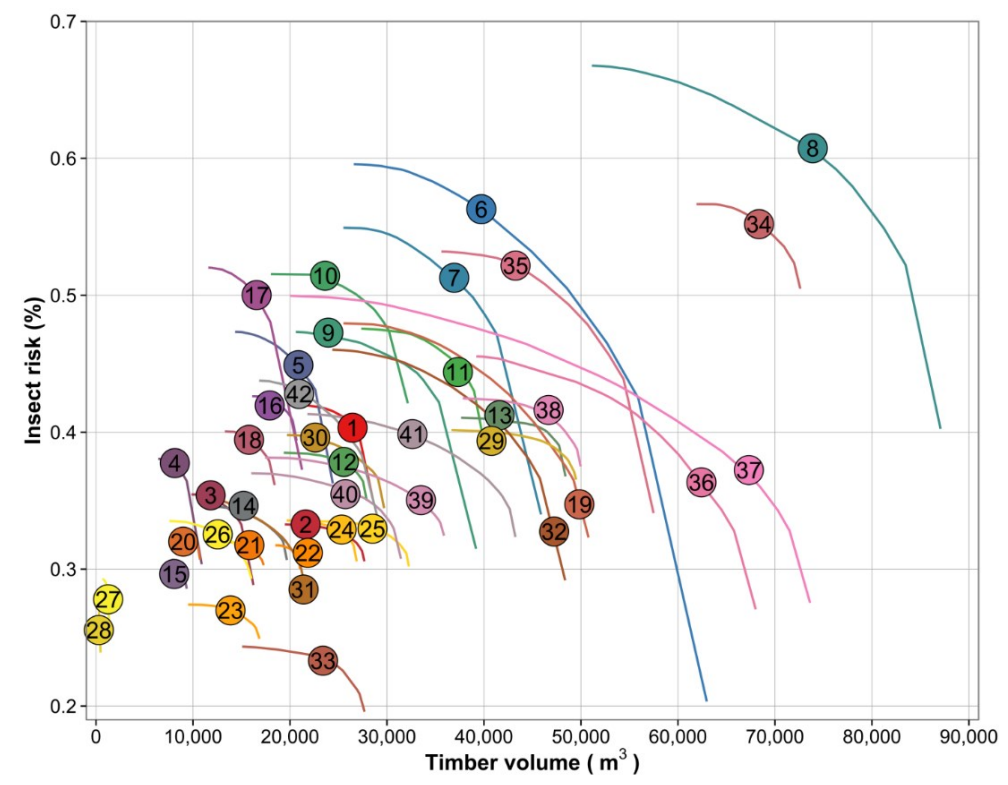

Figure 8. Production possibility frontier between total merchantable timber volume and treatment of the total landscape level insect risk restoration problem on the Wallowa-Whitman National Forest. 


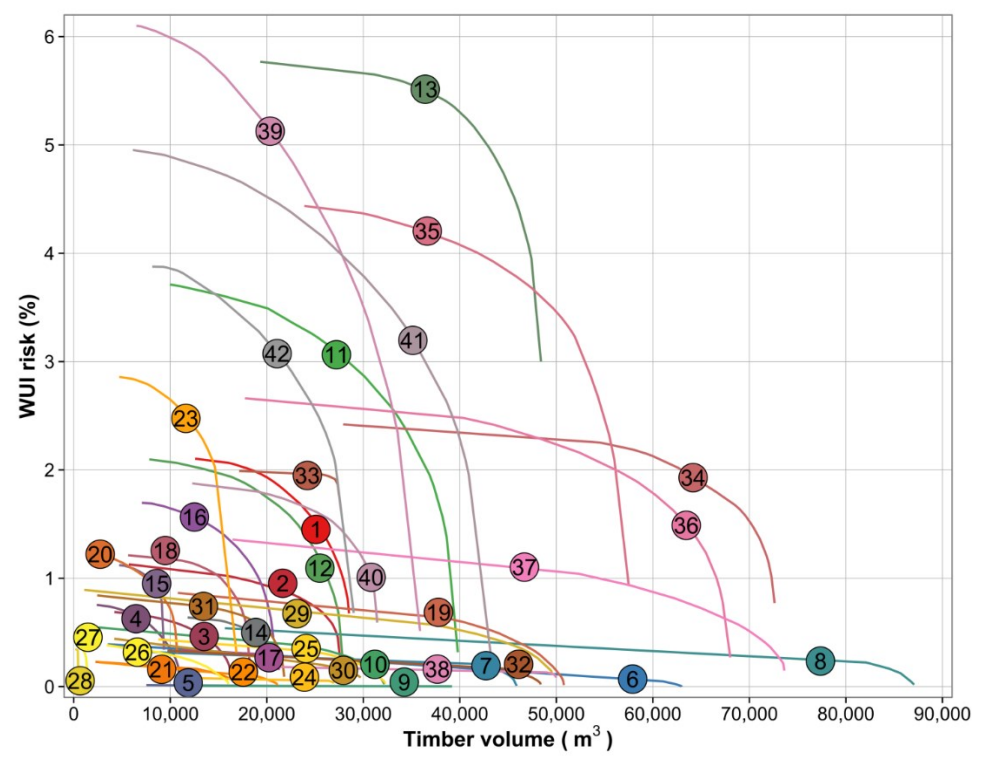

Figure 9. Production possibility frontier between total merchantable timber volume and treatment of the total landscape level WUI risk restoration problem on the Wallowa-Whitman National Forest.

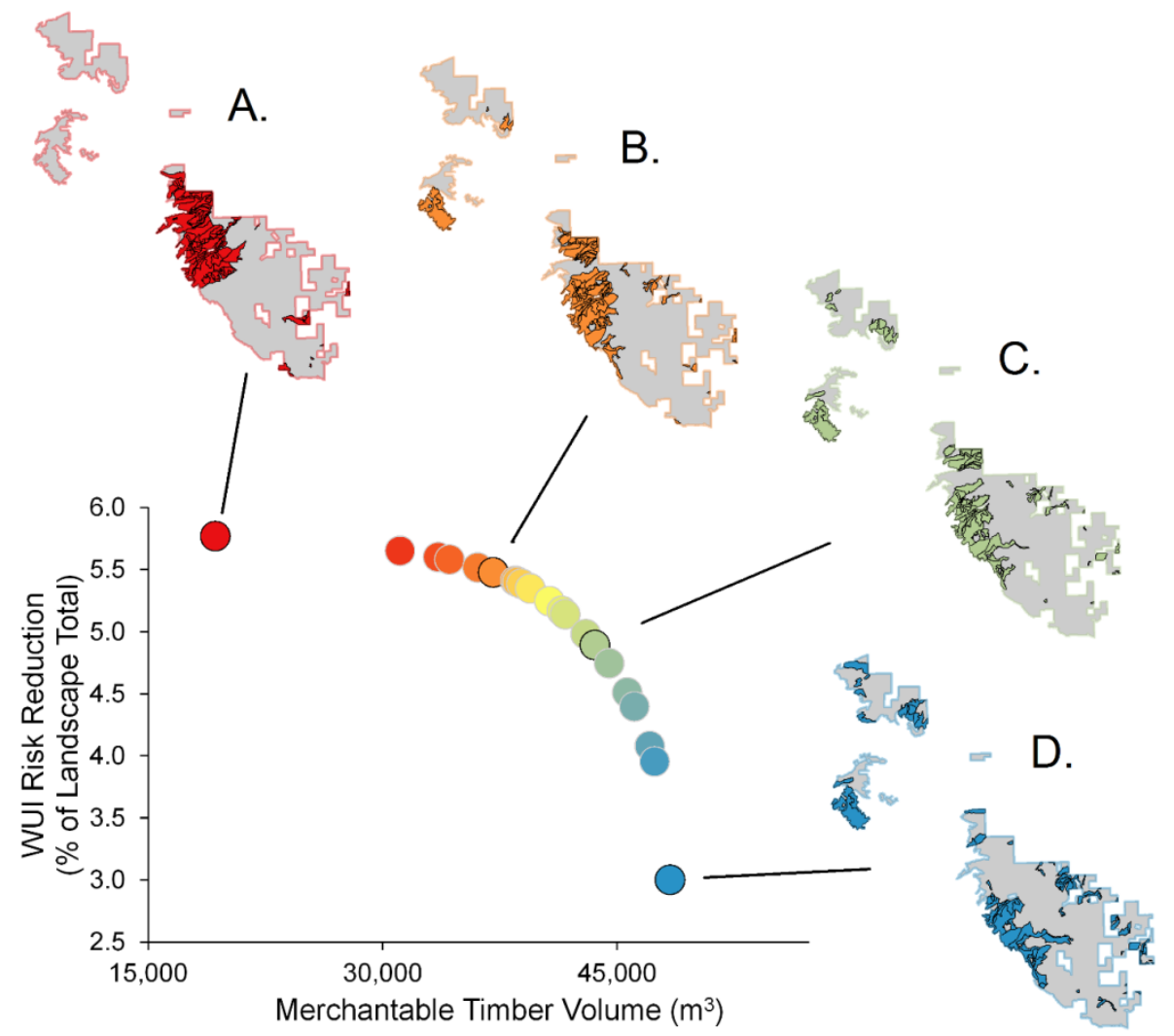

Figure 10. Production possibility frontier curve of WUI risk vs total merchantable timber volume for the Elkhorn Face planning area (PA13). Mapped treatment stands illustrate how stand selection changes as timber production is emphasized over WUI risk reduction (A-D).

The PPFs depicting the relationship between insect risk and timber harvest volume (Figure 8) demonstrated much greater tradeoffs than were found with vegetation departure. The planning area with the highest potential attainment for both objectives came at a high opportunity cost for one or the 
other (e.g., East Face, PA8). Planning areas such as Sage (PA34) where there was little tradeoff present, demonstrate the general collocation of objective variables and little variability between forest stands.

The steepest tradeoffs were seen in PPFs comparing WUI risk to timber harvest volume (Figure 9). Efforts to mitigate WUI risk from planning areas with the highest possible attainment came at a steep tradeoff with timber production and therefore would require significant subsidies to offset the cost of treatments. The lack of timber volume in close proximity to the urban areas where WUI wildfire risk is greatest could explain this steep tradeoff relationship. A large number of planning areas had little potential to address any WUI risk and therefore the PPFs had little slope.

Very steep tradeoffs relationships such as in the PPFs comparing WUI risk to timber harvest volume highlight the need to prioritize stand selection within planning areas in order to balance project economics with joint attainment of restoration goals. Individual stand selection as seen in Figure 10 illustrates how restoration priorities define stand selection and overall project attainment. Each point on the graph represents a unique combination of stands selected for treatment and their contribution towards meeting desired objectives.

Finally, the PPFs analyzing wildfire hazard and timber harvest volume (Figure 11) also showed steep tradeoffs although for a larger number of planning areas than WUI risk. Treatment of the majority of stands had the potential to greatly reduce wildfire hazard on the landscape but increased production of timber volume resulted in a steep tradeoff of wildfire hazard reduction. These tradeoffs area a result of flame length calculations within the simulation. Stands that have experienced infilling of grand-fir would have higher relative fire hazard (crown fire) due to the presence of ladder fuels but would also have less available merchantable timber volume due to the small average diameter of trees present. The PPFs also illustrate planning areas that could be considered a low restoration priority such as Sundry (PA15) where there were very few choices in regards to both timber production and wildfire hazard reduction.

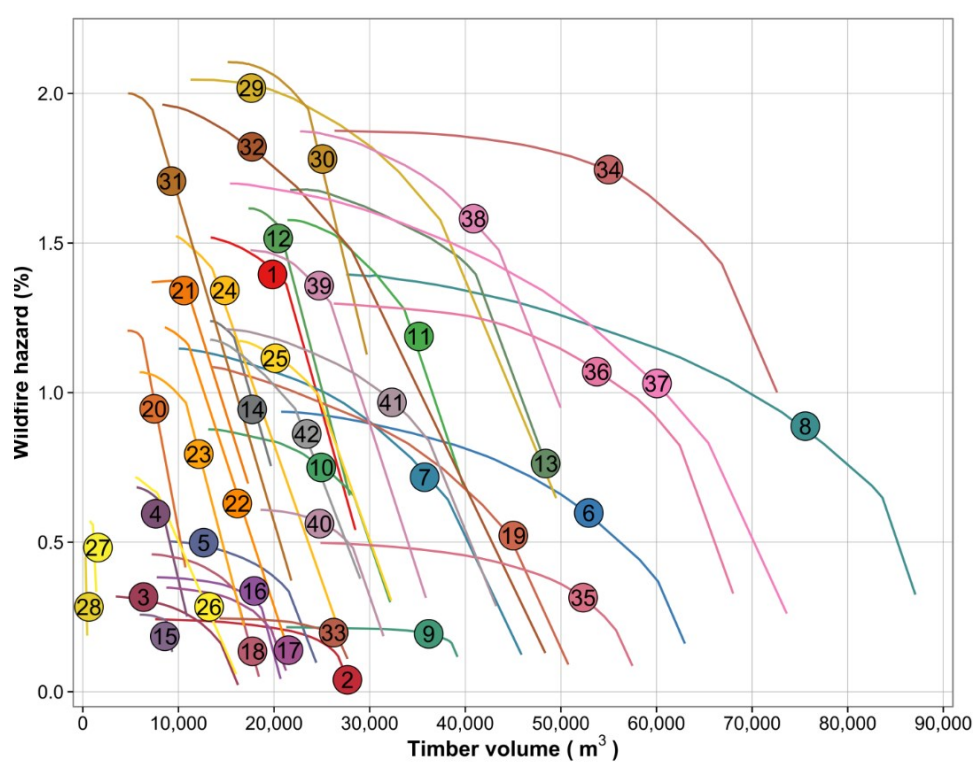

Figure 11. Production possibility frontier between total merchantable timber volume and treatment of the total landscape level wildfire hazard restoration problem on the Wallowa-Whitman National Forest.

\section{Discussion}

Large-scale insect and wildfire disturbances and changing climatic patterns pose growing challenges to land managers tasked with managing ecosystem services in temperate forests. Implementation of landscape level forest restoration treatments is a key component in reducing human and ecological losses from these disturbances. Restoration programs rely on provisional ecosystem services in the form of raw wood materials as a mechanism for offsetting treatment costs. Utilizing 
spatial planning tools to identify restoration priorities and analyze tradeoffs between attainment of restoration goals and timber volume production can leverage limited management budgets to improve the effectiveness of restoration programs [15].

The application of the LTD model to prioritize planning areas represents a new approach for identifying high-priority landscapes and improving efficiency of restoration programs. The location of high-priority restoration areas varied widely across the study area and between management objectives, illustrating the spatial complexity associated with multi-objective restoration programs. While many high-priority planning areas identified in our analyses were consistent with recent restoration projects on the Forest, several recent projects were located in low-priority areas. These projects highlight opportunities where utilizing decision support tools can help improve restoration planning efficiencies (Table 1).

Balancing competing objectives in restoration programs (e.g., vegetation departure, WUI risk) is an important step in the prioritization process for achieving long-term restoration goals. Current US federal forest policy assumes strong spatial correlation among various restoration goals [50]. However, we found limited opportunities to concurrently achieve multiple management objectives at the stand level due to a scarcity of lands meeting multiple objectives (Figure 6). This inability to address multiple restoration objectives at the stand level led to steep tradeoffs within planning areas based on stand treatment selection. Additionally, we found some restoration objectives had greater utility as a priority metric at the planning area scale thus indicating that objectives must be carefully selected to match the spatial distribution of forest stressors. Prioritization of scarce restoration objectives can allow for the joint production of widely available forest stressors (vegetation departure, insect risk) at the stand scale once planning area priorities have been established.

In addition to meeting identified restoration objectives, forest restoration projects have the potential to offset treatment cost through production of timber revenues. The development of economically viable projects that meet restoration objectives was complicated by planning areas exhibiting steep tradeoffs between multiple objectives. The steepest restoration tradeoffs were found in modeled projects addressing WUI risk or wildfire hazard, where developing projects that meet both economic and fire protection goals will be challenging. These tradeoffs resulted from a lack of colocation of restoration objectives and provisional ecosystem services at the stand level and emphasize the importance of prioritizing stand selection in order to meet restoration goals.

Fostering public support for forest management actions that include the use of mechanical treatments to produce wood products can be difficult [51,52]. Mapping landscape priorities using the framework presented provides a quantitative and transparent process for prioritization, enhancing understanding and accessibility of planning activities at the national forest scale. Additionally, visualizing project options with PPFs can illustrate inherent management tradeoffs across alternative and potentially competing restoration strategies, as well as highlight landscapes where joint attainment of goals may be possible. New ways to clearly articulate and quantify management options can help facilitate interaction with stakeholder and collaborative planning groups fulfilling an important role in restoration programs [53].

Despite the benefits of quantitative decision support tools for locating optimal project areas, examining tradeoffs, and as a communication framework to improve management transparency, these tools are not widely used within US land management agencies. For instance, the USDA Forest Service has previously used linear programming models including FORPLAN [54] and Spectrum [55], and state and transition models [56] for forest planning to meet the requirements of federal legislation [57]. However, prioritization of projects within Forests relies on ad hoc analyses that use field observations with GIS and inventory data. Tools such as Marxan with Zones [12], and Ecosystem Management Decision Support (EMDS, [58]) could be applied to support planning efforts, but these tools have not been widely adopted in the field due to their user support requirements. PPFs provide transparency to managers compared to multi-criteria decision making tools where impacts of individual variables are potentially diluted within the models. Since relatively few variables drive restoration planning 
decisions, leveraging more complex models to handle large numbers of variables does not offer clear advantages. Efforts to bridge the current gap between technological advancements in quantitative decision-support science and the tangible needs of forest managers need to focus on model accessibility and improved on-the-ground applicability.

This work builds on earlier applications of the LTD [48] by using the model to prioritize pre-existing planning areas through optimizing treatments of individual stands within each area. We also show how PPFs for each planning area can be collectively examined to understand tradeoffs within and among planning areas on the Forest. Our results provide an exploratory analysis in leveraging economic principles to improve restoration planning effectiveness. Modeling restoration programs poses many challenges and a number of assumptions were made to complete the current study. For instance, we assumed modeled restoration treatments would address each of the identified restoration objectives (i.e., vegetation departure, insect risk, WUI risk, and wildfire hazard) concurrently with an appropriate silvicultural treatment. Additionally, we assumed treatments would be operationally feasible despite potential on-the-ground challenges (e.g., steep slopes, lack of road access). These assumptions, however, are not inconsistent with assumptions made during National Forest System operational project planning and prioritization [49].

Historically, restoration efforts have often been piecemeal, emphasizing one or only a few forest stressors that garner public attention, yet fail to address the complex suite of stressors and their potential spatial interactions [59]. Cumulative stress on forest ecosystems is driven by multiple disturbances and their inherent relationships with one another, and future work should expand on these efforts to understand tradeoffs between multiple restoration objectives being simultaneously prioritized [60]. Additional work is also needed to expand the evaluation ability of current project efficiencies compared to modeled optimal benchmarks, as well as to analyze the nature of restoration tradeoffs at larger spatial scales. Prioritization work is currently being expanded to include the 82 national forests in the western US as well as to compare optimally generated project boundaries using the LTD model with those currently being used by land managers. Finally, while this paper has focused on dry forest restoration in the western US, the planning framework and results are applicable to terrestrial restoration programs worldwide. The ability to identify restoration priorities and understand tradeoffs between competing objectives will improve restoration program efficiency as well as management communication, thus potentially resulting in greater public trust and future programmatic success in maintaining ecosystem services.

Acknowledgments: We thank Kate Marcille for providing comments and suggestions on an earlier draft. We also thank Ken Bunzel for geospatial assistance, and Stephen Hawkins and Larry Sandoval for their input and local expertise. Stu Britain provided coding and technical support for the LTD model. This study was supported by funding from the USDA Forest Service, Pacific Northwest Region.

Author Contributions: Alan Ager was responsible for the study design. Kevin Vogler ran the model simulations and wrote the manuscript. Michelle Day conducted GIS analysis and graphical results and helped prepare the manuscript. Michael Jennings generated the insect data. All authors communicated on the results and interpretation of results and commented on and edited the manuscript at all stages.

Conflicts of Interest: The authors declare no conflicts of interest.

\section{References}

1. Hessburg, P.F.; Agee, J.K.; Franklin, J.F. Dry forests and wildland fires of the inland Northwest USA: Contrasting the landscape ecology of the pre-settlement and modern eras. For. Ecol. Manag. 2005, 211, 117-139. [CrossRef]

2. Meddens, A.J.; Hicke, J.A.; Ferguson, C.A. Spatiotemporal patterns of observed bark beetle-caused tree mortality in British Columbia and the western United States. Ecol. Appl. 2012, 22, 1876-1891. [CrossRef] [PubMed]

3. Aerts, R.; Honnay, O. Forest restoration, biodiversity and ecosystem functioning. BMC Ecol. 2011, 11, 29. [CrossRef] [PubMed] 
4. Westerling, A.L.; Hidalgo, H.G.; Cayan, D.R.; Swetnam, T.W. Warming and earlier spring increase western U.S. forest wildfire activity. Science 2006, 313, 940-943. [CrossRef] [PubMed]

5. Bentz, B.; Régnière, J.; Fettig, C.; Hansen, E.; Hayes, J.; Hicke, J.; Kelsey, R.; Negrón, J.; Seybold, S. Climate change and bark beetles of the western United States and Canada: Direct and indirect effects. Bioscience 2010, 60, 602-613. [CrossRef]

6. Hansen, A.J.; Neilson, R.P.; Dale, V.H.; Flather, C.H.; Iverson, L.R.; Currie, D.J.; Shafer, S.; Cook, R.; Bartlein, P.J. Global change in forests: Responses of species, communities, and biomes interactions between climate change and land use are projected to cause large shifts in biodiversity. Bioscience 2001, 51, 765-779. [CrossRef]

7. USDA Forest Service. Increasing the Pace of Restoration and Job Creation on Our National Forests; United States Department of Agriculture, Forest Service: Washington, DC, USA, 2012. Available online: http://www.fs.fed.us/sites/default/files/media/types/publication/field_pdf/increasing-pace-restorationjob-creation-2012.pdf (accessed on 1 October 2015).

8. Food and Agriculture Organization. Global Forest Resources Assessment; Main Report, Report No.: 163; FAO: Rome, Italy, 2010.

9. Agee, J.K.; Skinner, C.N. Basic principles of forest fuel reduction treatments. For. Ecol. Manag. 2005, 211, 83-96. [CrossRef]

10. Maron, M.; Cockfield, G. Managing trade-offs in landscape restoration and revegetation projects. Ecol. Appl. 2008, 18, 2041-2049. [CrossRef] [PubMed]

11. Reynolds, K. EMDS 3.0: A modeling framework for coping with complexity in environmental assessment and planning. Sci. China Ser. E 2006, 49, 63-75. [CrossRef]

12. Watts, M.E.; Ball, I.R.; Stewart, R.S.; Klein, C.J.; Wilson, K.; Steinback, C.; Lourival, R.; Kircher, L.; Possingham, H.P. Marxan with Zones: Software for optimal conservation based land- and sea-use zoning. Environ. Model. Softw. 2009, 24, 1513-1521. [CrossRef]

13. Hof, J.; Bevers, M. Spatial Optimization in Ecological Applications; Columbia University Press: New York, NY, USA, 2002; p. 261.

14. Segura, M.; Ray, D.; Maroto, C. Decision support systems for forest management: A comparative analysis and assessment. Comput. Electron. Agric. 2014, 101, 55-67. [CrossRef]

15. Rappaport, D.I.; Tambosi, L.R.; Metzger, J.P. A landscape triage approach: Combining spatial and temporal dynamics to prioritize restoration and conservation. J. Appl. Ecol. 2015, 52, 590-601. [CrossRef]

16. Polasky, S.; Nelson, E.; Camm, J.; Csuti, B.; Fackler, P.; Lonsdorf, E.; Montgomery, C.; White, D.; Arthur, J.; Garber-Yonts, B.; et al. Where to put things? Spatial land management to sustain biodiversity and economic returns. Biol. Conserv. 2008, 141, 1505-1524. [CrossRef]

17. Levin, N.; Watson, J.E.; Joseph, L.N.; Grantham, H.S.; Hadar, L.; Apel, N.; Perevolotsky, A.; DeMalach, N.; Possingham, H.P.; Kark, S. A framework for systematic conservation planning and management of Mediterranean landscapes. Biol. Conserv. 2013, 158, 371-383. [CrossRef]

18. Schroter, M.; Rusch, G.M.; Barton, D.N.; Blumentrath, S.; Norden, B. Ecosystem services and opportunity costs shift spatial priorities for conserving forest biodiversity. PLoS ONE 2014, 9, e112557. [CrossRef] [PubMed]

19. Klein, C.J.; Steinback, C.; Watts, M.; Scholz, A.J.; Possingham, H.P. Spatial marine zoning for fisheries and conservation. Front. Ecol. Environ. 2009, 8, 349-353. [CrossRef]

20. Klein, C.J.; Tulloch, V.J.; Halpern, B.S.; Selkoe, K.A.; Watts, M.E.; Steinback, C.; Scholz, A.; Possingham, H.P. Tradeoffs in marine reserve design: Habitat condition, representation, and socioeconomic costs. Conserv. Lett. 2013, 6, 324-332. [CrossRef]

21. Yates, K.L.; Schoeman, D.S.; Klein, C.J. Ocean zoning for conservation, fisheries and marine renewable energy: Assessing trade-offs and co-location opportunities. J. Environ. Manag. 2015, 152, 201-209. [CrossRef] [PubMed]

22. Kline, J.D.; Mazzotta, M. Evaluating Tradeoffs Among Ecosystem Services in the Management of Public Lands; Report No.: PNW-GTR-865; USDA Forest Service, Pacific Northwest Research Station: Portland, OR, USA, 2012.

23. Filip, G.M.; Parks, C.A.; Wickman, B.E.; Mitchell, R.G. Tree wound dynamics in thinned and unthinned stands of grand fir, ponderosa pine, and lodgepole pine in eastern Oregon. Northwest Sci. 1995, 69, $276-283$.

24. Wickman, B.E. Forest Health in the Blue Mountains: The Influence of Insects and Diseases; Report No.: PNW-GTR-295; USDA Forest Service, Pacific Northwest Reseach Station: Portland, OR, USA, 1992. 
25. Short, K.C. A spatial database of wildfire in the United States, 1992-2011. Earth Syst. Sci. Data 2014, 6, 1-27. [CrossRef]

26. Landfire. Landfire Vegetation Departure. 2013. Available online: http://landfire.cr.usgs.gov/viewer/ (accessed on 6 August 2013).

27. Barrett, S.; Havlina, D.; Jones, J.; Hann, W.; Frame, C.; Hamilton, D.; Schon, K.; DeMeo, T.; Hutter, L.; Menakis, J. Interagency Fire Regime Condition Class (FRCC) Guidebook; Version 3.0. Available online: www.frames.gov/partner-sites/frcc/frcc-guidebook-and-forms/ (accessed on 20 November 2015).

28. Rollins, M.; Ward, B.; Dillon, G.; Pratt, S.; Wolf, A. Developing the Landfire Fire Regime Data Products. 2007. Available online: http://www.landfire.gov/downloadfile.php?file=Developing the_LANDFIRE_Fire_Regime_Data_Products.pdf (accessed on 15 May 2015).

29. Jennings, M.; (Wallowa-Whitman National Forest, La Grande Ranger District, La Grande, OR, USA). Insect risk data for the Wallowa-Whitman National Forest. Personal communication, 2014.

30. Ohmann, J.L.; Gregory, M.J. Predictive mapping of forest composition and structure with direct gradient analysis and nearest-neighbor imputation in coastal Oregon, USA. Can. J. For. Res. 2002, 32, 725-741. [CrossRef]

31. Dixon, G.E. Essential FVS: A User's Guide to the Forest Vegetation Simulator; USDA Forest Service, Forest Management Service Center: Fort Collins, CO, USA, 2002; Available online: http://www.fs.fed.us/ $\mathrm{fmsc} / \mathrm{ftp} / \mathrm{fvs} / \mathrm{docs} / \mathrm{gtr} /$ EssentialFVS.pdf (accessed on 1 October 2015).

32. Ager, A.A.; McMahan, A.J.; Barrett, J.J.; McHugh, C.W. A simulation study of thinning and fuel treatments on a wildland-urban interface in eastern Oregon, USA. Landsc. Urban Plan. 2007, 80, 292-300. [CrossRef]

33. Ager, A.A.; Vaillant, N.M.; Finney, M.A. A comparison of landscape fuel treatment strategies to mitigate wildland fire risk in the urban interface and preserve old forest structure. For. Ecol. Manag. 2010, 259, 1556-1570. [CrossRef]

34. Reineke, L.H. Perfecting a stand-density index for even-aged forests. J. Agric. Res. 1933, 46, 627-638.

35. Cochran, P.H.; Geist, J.M.; Clemens, D.L.; Clausnitzer, R.R.; Powell, D.C. Suggested Stocking Levels for Forest Stands in Northeastern Oregon and Southeastern Washington; Report No.: PNW-RN-513; USDA Forest Service, Pacific Northwest Research Station: Portland, OR, USA, 1994.

36. Hall, E.C. Pacific Northwest Ecoclass Codes for Seral and Potential Natural Communities; Report No.: PNW-GTR-418; USDA Forest Service, Pacific Northwest Research Station: Portland, OR, USA, 1998.

37. Johnson, C.G., Jr.; Clausnitzer, R.R. Plant Associations of the Blue and Ochoco Mountains; Report No.: R6-ERW-TP-036-92; USDA Forest Service, Pacific Northwest Region: Portland, OR, USA, 1992.

38. Keyser, C.E.; Dixon, G.E. Blue Mountains (BM) Variant Overview-Forest Vegetation Simulator; USDA Forest Service, Forest Management Service Center: Fort Collins, CO, USA, 2015.

39. Radeloff, V.C.; Hammer, R.B.; Stewart, S.I.; Fried, J.S.; Holcomb, S.S.; McKeefry, J.F. The wildland-urban interface in the United States. Ecol. Appl. 2005, 15, 799-805. [CrossRef]

40. Ager, A.A.; Day, M.A.; McHugh, C.W.; Short, K.; Gilbertson-Day, J.; Finney, M.A.; Calkin, D.E. Wildfire exposure and fuel management on western US national forests. J. Environ. Manag. 2014, 145, 54-70. [CrossRef] [PubMed]

41. Finney, M.A.; McHugh, C.W.; Grenfell, I.C.; Riley, K.L.; Short, K.C. A simulation of probabilistic wildfire risk components for the continental United States. Stoch. Environ. Res. Risk Assess. 2011, 25, 973-1000. [CrossRef]

42. Western Regional Climate Center. RAWS USA Climate Archive. 2014. Available online: http://www.raws.dri.edu/ (accessed on 1 October 2015).

43. Forests and Rangelands. Fire Program Analysis. 2010. Available online: http://www.fpa.nifc.gov/ (accessed on 28 November 2012).

44. Finney, M.A. An overview of FlamMap fire modeling capabilities. In Proceedings of the Fuels Management-How to Measure Success, RMRS-P-41, Portland, OR, USA, 28-30 March 2006; Andrews, P.L., Butler, B.W., Eds.; USDA Forest Service, Rocky Mountain Research Station: Fort Collins, CO, USA, 2006; pp. 213-220.

45. Rollins, M.G. Landfire: A nationally consistent vegetation, wildland fire, and fuel assessment. Int. J. Wildland Fire 2009, 18, 235-249. [CrossRef]

46. Landfire. Homepage of the Landfire Project. 2013. Available online: http://www.landfire.gov/index.php (accessed on 26 August 2009). 
47. Scott, J.H.; Burgan, R.E. Standard Fire Behavior Fuel Models: A Comprehensive Set for Use with Rothermel's Surface Fire Spread Model; Report No.: RMRS-GTR-153; USDA Forest Service, Rocky Mountain Research Station: Fort Collins, CO, USA, 2005; Available online: http://treesearch.fs.fed.us/pubs/9521 (accessed on 20 November 2015).

48. Ager, A.A.; Vaillant, N.M.; McMahan, A. Restoration of fire in managed forests: A model to prioritize landscapes and analyze tradeoffs. Ecosphere 2013, 4, 29. [CrossRef]

49. Brown, R.T.; Agee, J.K.; Franklin, J.F. Forest restoration and fire: Principles in the context of place. Conserv. Biol. 2004, 18, 903-912. [CrossRef]

50. USDA Forest Service. Ecosystem Restoration: A Framework for Restoring and Maintaining the National Forests and Grasslands; USDA Forest Service: Washington, DC, USA, 2006; Available online: http://www.fs.fed.us/restoration/documents/RestFramework_final_010606.pdf (accessed on 20 August 2015).

51. Johnson, J.F.; Bengston, D.N.; Fan, D.P.; Nelson, K.C. US policy response to the fuels management problem: An analysis of the public debate about the Healthy Forests Initiative and the Healthy Forests Restoration Act. In Proceedings of the Fuels Management-How to Measure Success, RMRS-P-41, Portland, OR, USA, 28-30 March 2006; Andrews, P.L., Butler, B.W., Eds.; USDA Forest Service, Rocky Mountain Research Station: Fort Collins, CO, USA, 2006; pp. 59-66.

52. Lachapelle, P.R.; McCool, S.F. The role of trust in community wildland fire protection planning. Soc. Nat. Resour. 2012, 25, 321-335. [CrossRef]

53. Butler, W.H.; Goldstein, B.E. The US Fire Learning Network: Springing a rigidity trap through multiscalar collaborative networks. Ecol. Soc. 2010, 15, 21.

54. Iverson, D.C.; Alston, R.M. The Genesis of Forplan: A Historical and Analytical Review of Forest Service Planning Models; Report No.: INT-214; USDA Forest Service, Intermountain Research Station: Ogden, UT, USA, 1986.

55. Mowrer, H.T. Decision Support Systems for Ecosystem Management: An Evaluation of Existing Systems; Report No.: RM-GTR-296; USDA Forest Service, Rocky Mountain Forest and Range Experiment Station: Fort Collins, CO, USA, 1997.

56. Hemstrom, M.A.; Merzenich, J.; Reger, A.; Wales, B. Integrated analysis of landscape management scenarios using state and transition models in the upper Grande Ronde River Subbasin, Oregon, USA. Landsc. Urban Plan. 2007, 80, 198-211. [CrossRef]

57. USDA. 36 CFR Part 219. National forest system land management planning. Fed. Regist. 2012, 77, 21162-21276.

58. Reynolds, K.M. EMDS: Using a logic framework to assess forest ecosystem sustainability. J. For. 2001, 99, 26-30.

59. Allan, J.D.; McIntyre, P.B.; Smith, S.D.P.; Halpern, B.S.; Boyer, G.L.; Buchsbaum, A.; Burton, G.A., Jr.; Campbell, L.M.; Chadderton, W.L.; Ciborowski, J.J.H.; et al. Joint analysis of stressors and ecosystem services to enhance restoration effectiveness. Proc. Natl. Acad. Sci. USA 2013, 110, 372-377. [CrossRef] [PubMed]

60. Groeneveld, R.; Grashof-Bokdam, C.; van Ierland, E. Metapopulations in agricultural landscapes: A spatially explicit trade-off analysis. J. Environ. Plan. Manag. 2005, 48, 527-547. [CrossRef]

(C) 2015 by the authors; licensee MDPI, Basel, Switzerland. This article is an open access article distributed under the terms and conditions of the Creative Commons by Attribution (CC-BY) license (http:/ / creativecommons.org/licenses/by/4.0/). 